Uniwersytet w Białymstoku

Wydział Filologiczny

Kolegium Językoznawstwa

tel.: +48 857457499

e-mail: k.grabowska@uwb.edu.pl

ORCID ID: https://orcid.org/0000-0002-0313-5205

\title{
Przekształcenia w obrębie systemu imiesłowów czynnych w języku starobiałoruskim na przykładzie wybranych latopisów białorusko-litewskich
}

Słowa kluczowe: latopisarstwo Wielkiego Księstwa Litewskiego, język starobiałoruski, morfologia, imiesłowy czynne

Sięgające swymi początkami XII wieku latopisarstwo Wielkiego Księstwa Litewskiego (dalej: WKL) stanowi bogate źródło wiedzy nie tylko o przeszłości Białorusi, ale również dostarcza cennych informacji o fonetyce, morfologii, składni, leksyce i frazeologii języka starobiałoruskiego [Mixнeвіч 1994, 305]. Latopisy łączy pochodzenie i wiele wspólnych części, jednak nie są identyczne pod względem objętości, zawartości treściowej, wydźwięku ideowego i opracowania redaktorskiego tekstu. W odniesieniu do cech językowych omawiane zabytki również wykazują niejednorodność, wynikającą z kompilowanego charakteru tego typu literatury oraz różnic czasowych, dzielących powstanie poszczególnych redakcji.

Szczególne miejsce w historii latopisarstwa białoruskiego zajmują latopisy XIV-XVII w. posiadające rangę ogólnopaństwowych w WKL. Pojawiają się $\mathrm{w}$ nich lokalne elementy językowe odzwierciedlające charakterystyczne cechy formujących się w tym okresie języków białoruskiego i ukraińskiego [Микитась 1978, 97-103]. Konieczność zbadania języka latopisów starobiałoruskich podkreślał A. I. Żurawskij, argumentując, że „без даследавання гэтай мовы немагчыма зразумець тыя складаныя працэсы, якія адбываліся на шляху станаўлення беларускай літаратурнай мовы" [Жураў- 
скі 1983, 6]. Badacz uważał, iż na podstawie późniejszych zachowanych odpisów można tylko przypuszczać, jak wyglądał język najstarszych oryginalnych latopisów WKL. Jego zdaniem, stanowił on połączenie żywej mowy z elementami języka cerkiewnosłowiańskiego [Жураўскі 1961, 111].

Celem niniejszego artykułu jest przedstawienie zmian, które zaszły w systemie starobiałoruskich imiesłowów czynnych w porównaniu do stanu ogólnoruskiego. Jako materiał badawczy posłużyły teksty dwóch zabytków piśmiennictwa WKL opublikowane w XXXV tomie Полного собрания русских летописей pod redakcją N.N. Ułaszczyka [Улащик 1980, 36-67, 128-144]: Kroniki supraskiej (1519 r.) reprezentującej pierwszą redakcję latopisów białorusko-litewskich oraz Latopisu Krasinskich będącego najstarszym odpisem drugiej redakcji powstałym w połowie XVI w. Należy podkreślić, iż ponad połowę tekstu Kroniki supraskiej stanowi część ogólnoruska, będąca kompilacją wcześniejszych kronik staroruskich. W skład zabytku wchodzą ponadto tzw. „smoleńska częśc”" oraz Latopis wielkich ksiażąt litewskich [Чемерицкий 1981, 182] - pierwszy oryginalny utwór powstały na terenie WKL. W wyniku połączenia Latopisu wielkich ksiażat litewskich zapożyczonego z pierwszej redakcji i Kroniki Wielkiego Księstwa Litewskiego $i$ Żmudzkiego powstał nowy zabytek - druga redakcja latopisów białorusko-litewskich, reprezentowany m.in. przez odpis Krasińskich. W zabytku tym poszczególne części Latopisu wielkich ksią̇ąt litewskich mają formę samodzielnych fragmentów opatrzonych podtytułami. Tekst Latopisu Krasińskich jest niepełny, brak w nim bowiem końca Kroniki Wielkiego Księstwa Litewskiego $i$ Żmudzkiego oraz ostatniej strony Latopisu wielkich ksiażat litewskich.

Analizowane zabytki bogato dokumentują wszystkie typy imiesłowów czynnych prostych, natomiast imiesłowy złożone pojawiają się w nich w sposób marginalny. Różnorodność przykładów wyekscerpowanych z obu tekstów, nieprzystawalność przypadka oraz osoby i liczby świadczą o daleko posuniętym procesie przekształceń starych form imiesłowów przymiotnikowych.

\section{Imiesłowy czynne czasu teraźniejszego}

Imiesłowy czynne czasu teraźniejszego charakteryzują się bogactwem form, świadczącym o silnym związku latopisów zarówno z żywym językiem okresu powstania zabytków, jak również z tradycją cerkiewnosłowiańską.

Pod tym względem szczególnie wyróżnia się tekst Kroniki supraskiej, w którym znalazły poświadczenie cerkiewnosłowiańskie formy na -bl: 
бЂ Олегь мнящися мимоиды (7 S.1 ), $\underline{\text { яди, }}$, рече, хлЂб мои (14 S.), постави порокь 12 не могы розбити стень (32 S.), и приде ко Каменьцю, и не могы разбити стень (32v S.), изылде горды (...) и не имь вида человеча $(54 \mathrm{v} \mathrm{S}$.). Zabytek dokumentuje również stare formy na $-a /-я$ $\mathrm{w}$ nom. sg. masc.: бояся (19 S.), будя (88 S.), возирая (25 S.), глаголя (14 S.), дая (42v S.), добиваяся (61v S.), доходя (74v S.), им Ђя (10 S.), надияся (93v S.), обретая (61v S.), помщая (96 S.), приводя (16 S.), проплакивая (91 S.), прося (105v S.), разгоряся (28v S.), растляя (16 S.), роздая (6v S.), соговоряся (69 S.), стоя (40v S.), утаяся (39 S.), хваляся (55 S.), не хотя (15v S.), rozszerzone na formy pl., por.: приидоша послове (...) прося мира и живота своеи братьи (39v S.), и на лБто полотяне и видбляне, не цюя собе помощи ниоткуля (78 S.), велиии ординьскыи князи, полеиаяся ему под великую служьбу (81 S.), ㅆязи великьи Витовт со отиемь своимь (...) обадва по Бде в рать ко Яглу надияся на тыли правды (95v S.). Wykorzystanie starych form masc. i neutr. w znaczeniu pl. było częstym zjawiskiem w piśmiennictwie końca XV - początku XVI w. [Булыка, Жураўскі, Крамко, Свяжынскі 1988, 252]. W analogicznych fragmentach późniejszego Latopisu Krasińskich w miejscu starych form na - $я$ pojawiają się imiesłowy wyrównane do zunifikowanej formy nom. fem., por.: надЂючися на мазовецького князя (75v K.), а то все помщиваючи Воидила (77 K.), почнеть опять жаловатся, проплакиваючи (74v К.), пришли посльь (...) просячи у него дочки (80 К.), князь великьи Витовт с отцом своим, князем великьлм Кестутьем, обадва поедуть у воиска Якгаилово на тыи присяги надЂючися (77 K.). Nieliczne imiesłowy posiadają staroruską końcówkę - a: буда (99 S.), не возма (100v S.; 81 K.), вылма (106v S.). Taki typ końcówki utrzymywał się jeszcze w zabytkach XIV w. [Соболевский 2005, 259]. Obecność form na -a może świadczyć o zastosowaniu świadomego zabiegu stylistycznego.

Już najstarsze zabytki piśmiennictwa staroruskiego dokumentują wahania w formach przypadków imiesłowów czynnych, wskazujące na proces zaniku paradygmatu deklinacyjnego [Борковский, Кузнецов 2007, 303]. Imiesłowy często nie są również kongruentne z podmiotem w rodzaju i liczbie, por.: видихомь ея идуще (58v S.), и видя святителя плачющеся и молящеся $(70$ S.), гребии же седяши $(29$ S.), почн Бть Керстутеи жаловатиа (...) рекуии (74v K.). Utrata przez nie funkcji przydawki i umoc-

\footnotetext{
1 Numeracja stron przyjęta $\mathrm{w}$ niniejszym artykule jest zgodna z numeracją użytą $\mathrm{w}$ Полном собрании русских летописей. Inicjały podane w nawiasach obok numeracji stron oznaczają odpowiednio: S. - Kronika supraska, K. - Latopis Krasińskich.
} 
nienie się przy orzeczeniu w roli predykatu świadczą o przekształcaniu się krótkich imiesłowów przymiotnikowych w nieodmienne imiesłowy przysłówkowe [Иванов 1983, 361]. Badania historyków języka dowodzą, iż już pod koniec XIV w. funkcjonowały one jako uformowane części mowy. Starobiałoruskie zabytki końca XV - początku XVI w. demonstrują etap przekształcania się krótkich imiesłowów przymiotnikowych w przysłówkowe, przez co ich użycie w tekstach nie jest jeszcze ujednolicone. W latopisach powszechne są formy na $-a /-я \mathrm{w}$ znaczeniu imiesłowów przysłówkowych [Булыка, Жураўскі, Крамко, Свяжынскі 1988, 251-252]. Z Kroniki supraskiej zоstały wyekscerpowane przykłady użycia tych form zarówno w starej, jak i w nowej funkcji, por.: и живяше Олег мир им Бя с всими (10 S.), ино преблагыи бог не хотя смерти гр Бшьникомь (15v S.) / и сташа на СЂти станомь и ждуча $к$ собЂ брата Ярослава (24 S.). Na gruncie białoruskim w znaczeniu imiesłowów przysłówkowych rozwinęły się stare formy fem.

W świeckich i religijnych tekstach znajdujących się pod wpływem cerkiewnosłowiańskim, a nawet $\mathrm{w}$ oryginalnych białoruskich utworach imiesłowy na -uu często wchodzą w skład archaicznej konstrukcji dativus absolutus [Булыка, Жураўскі, Крамко 1979, 308-309]. Kronika supraska potwierdza szereg podobnych przykładów, aczkolwiek $\mathrm{w}$ tekście pojawiają się również starsze konstrukcje z formą celownika, por.: Игоревu же ходящи по Олгови (8v S.), принесь $\kappa$ митрополиту ту будуши князю великому Ивану Михаиловичь (65 S.), неколи будущи тому славному господарю (78v S.), князю ГлБбу седяши во Смоленсте и нача не в послушани быти (103v S.) / стояшю ему при краи моря, стрегуши обою пути (29 S.), сушю же ему в Нимчах (96v S.), а ㅆязю великому Витовту тогды держащю Луческь (100 S.), посхотевшю же князю Скиригаилу ехати (103 S.). Konstrukcja „celownika niezależnego” w późniejszym Latopisie Krasinskich tworzona jest z pomocą imiesłowów па -чи, por.: пануючи ему в земли в Жомоитьскои (66 K.), и будучи ему русином (68 К.), князю в Бликому пак Витовту, там мБшкаючи (77v К.), киязю Св Бтославу, стоячи под Мстиславлем городом и города добьваючи (79 К.), князю Володимерю Олкгирдовичу тогды будучи в КиевЂ (81 К.), в Бликому князю Якгаилу, держачи ему столець Полского кролевства (86 К.) / в Бликому князю Якгаилу и князю Скиргаилу, нБ могучи стояти против князю (77v K.), многим волостем литовским прислухаючи ему (79v K.) (w znaczeniu pl.). Użycie konstrukcji dativus absolutus było charakterystyczne dla latopisów, jednak zaznacza się również w innych gatunkach literackich, co świadczy o jej obecności w mowie żywej [Булыка, Жураўскі, Крамко, Свяжынскі 1988, 255]. 
W obu zabytkach bezwzględnie dominują nieodmienne imiesłowy czynne współczesne przedstawiające skostniałe formy nom. sg. fem. We wcześniejszej Kronice supraskiej są one reprezentowane głównie poprzez powszechne we wczesnym piśmiennictwie starobiałoruskim zapisy z cerkiewnosłowiańskim sufiksem -ur-., por.: Олга (...) ллаголющи (11v S.), звезда велика (...) на восточе восходящи (58v S.), река пресходящи всю землю человеческьи скоты пояющи, а сама не вмаляшися (81v S.), лядскои заставе, во Високом городе тогда сущи (101v S.) / яко от рада $\underline{\text { ему }}$ суши (7 S.), приде Олег (...) несущи (10 S.), стояшю ему при краи моря, стрегущи (29 S.), будущи князю великому (65 S.), тому с нимь во велицеи любви живущи (79 S.), Ягаилу держащи стол Краковского кролевъства (79v S.) (w znaczeniu masc.); иарие (...) глаголющи (17 S.), и они (...) сыплущи (16v S.), ㅎии бо не вЂдающи глаголють (18 S.), видиша ангели, помогающи Ярославу (20v S.), послаша посльи (...) просящи (22 S.), татарове (...) водящи со собою Володимера Юрьевичь (23 S.), собрав епископи (...) живущи (67v S.), людие емьлющи по улицаль (82v S.) (w znaczeniu pl.). Pod koniec XV wieku częstotliwość tego typu zapisów w starobiałoruskich zabytkach uległa znacznej redukcji [Булыка, Жураўскі, Крамко 1979, 289-290]. Należy podkreślić, iż w Kronice supraskiej zapisy imiesłowów z cerkiewnosłowiańskim sufiksem dominują we wszystkich rodzajach, por.:

dat. masc.: стояшю ему при краи моря (29 S.);

асc. masc.: види насад гребущь (29 S.), королевича мчаща под руку (29v S.) / уби служящего ему князя Семена Мстиславича (62v S.);

nom. neutr.: солнце крываво и луча испущая (57v S.);

dat. fem.: приходящеи русь (9v S.);

acc. fem.: види бо землю Рускую гибнущи (32v S.).

Dla porównania Kronika supraska poświadcza zaledwie kilka przykładów imiesłowów z sufiksem - - , por.: посла $\kappa$ нему ц्рарица, рекучи $(17 \mathrm{v} \mathrm{S}$.); вступи Олег на голову коневу, рекучи (10v S.), корол почаль просити князя великого Витовта, рекучи (107 S.); мужи (...) не платячи (10 S.), кияне шлются $\kappa$ Володимеру, рекучи $(14 \mathrm{v} \mathrm{S.),} \mathrm{ㅆязи} \mathrm{резанскыя} \mathrm{(...)}$ просячи помочи (22v S.), наши (...), биючи и секучи безь милости поганных (49 S.), от них завЂдали втамони а боискаки, приезьдяючи (104v S.), и ловячи в ловех пригодилося имь так (105v S.).

Język Latopisu Krasińskich charakteryzuje się konsekwentnym użyciem zunifikowanej formy nom. fem. z sufiksem - $\boldsymbol{~ - ~ k o r e l u j a ̨ c e j ~ z ~ r z e c z o w - ~}$

2 рода 
nikami wszystkich rodzajów i liczb, por.: будучи он в старости своеи (66v K.), киязь великии киевъскии Дмитреи, боячися великое сильь (66v K.), ㅆязь Мьстислав (...) хотячи его выгнати (68v K.), Шварнове княжачи на Новегородие (68v K.), нязь (...) милуючи подданьх своих $(69 \mathrm{v}$ K.), ㅆязь великыи Куковочти, милуючи матку свою $(69 \mathrm{v} \mathrm{K.),} \mathrm{Керстутеи} \mathrm{почнеть} \mathrm{опять} \mathrm{жаловатся,} \mathrm{проплакиваючи}$ (74v К.), князь в Бликыи Якааило (...) помщиваючи Воидила (77 К.), князь Скиргаило того нъ ведаючи (81v К.), Михаило к Смоленску не идучи (89 К.) / Парасковгия (...) мешкала там сем лБт, богу служечи и книги пишучи на иерков (68 K.) / многые, опускаючи именя а скарбы свои (64v K.), подданьи его, милуючи его (65v K.), оные мюди, мешькаючи около него (65v K.), панове, жалуючи господаря своего прироженого (70v K.), они не противячися поддалися (72 K.), обадва поедуть у воиска Якгаилово на тыи присяги надЂючися (77 K.), царь ордынскии и князи ордынские (..) прросячи собЂ иаря (86v K.), ㅆязи ордынские, нБ смеючи розгнБвати славного господаря (87 K.).

Starobiałoruskie zabytki piśmiennictwa II poł. XVI w. - I poł. XVII w. dokumentują zmianę ['a] $>[\mathrm{e}] \mathrm{w}$ sufiksie -яuи imiesłowów czynnych czasu teraźniejszego, co doprowadziło do powstania wariantów typu боронечь, просечь, ходечь [Булыка, Жураўскі, Крамко, Свяжынскі, 1988, 254]. Dodatkowo zapisy tego typu odzwierciedlały dyspalatalizację spółgłoski [‘č]. Z Latopisu Krasińskich zostały wyekscerpowane nieliczne przykłady ilustrujące zmianę sufiksu -ячu, jednak bez dyspalatalizacji [‘̌ c], por.: хотечu (64v K., 66v K.), ходечи (64v K.), служечи (68 K.), княжечи (70 K.).

W Kronice supraskiej formy pl. imiesłowów czasu teraźniejszego posiadają starosłowiański sufiks - u-. Formy nom. masc. z sufiksem - $\iota_{-}$pojawiają się zaledwie dwa razy, por.: ласкаюче (26 S.), пустяче (22 S.) / биюще (69v S.), могуще (58 S.), мучаще (98 S.), приходяще (79 S.), просяще (81 S.), рекуще (9v S.), секуще (26v S.). W Latopisie Krasińskich odnotowany został tylko jeden podobny przykład: священници поюue $(81 \mathrm{v} \mathrm{K}$.). Stare formy nom. masc. na -e funkcjonowały w białoruskim piśmiennictwie XV-XVI w. w roli okolicznika i podobnie jak formy fem. sg. na -учи/-ючи uległy procesowi adwerbializacji [Булыка, ЖКураўскі, Крамко, 1979, 308], por. przykłady z Latopisu supraskiego: и яшася греци по се, рекуще $(9 \mathrm{v} \mathrm{S.),} \mathrm{князи} \mathrm{же} \mathrm{резанскье} \mathrm{(...)} \mathrm{не} \mathrm{пустяче} \mathrm{ко} \mathrm{городом} \mathrm{своимь}$ (22 S.), Смолняне же не могуще терп Бти насилия от иноверных ляхов (58 S.), и людие же видивъши воплего, влачаху его на вече, биюще мало не до смерти (69v S.).

Pozostałe przykłady reprezentują imiesłowy złożone o regularnych końcówkach w gen. i dat., por.: 
gen.: ссущих (27 S.);

dat.: биющимься (27 S.), зовущимься (99 S.), сущимь (11 S.), творящимся (23 S.), хотяиимь (27 S.).

W udokumentowanej formie dat. fem.: владЋющьмь (100v S.) jer jest graficznym odpowiednikiem [e].

\section{Imiesłowy czynne czasu przeszłego}

Wyekscerpowane z zabytku formy imiesłowów czynnych czasu przeszłego I, kontynuują odziedziczoną z prasłowiańszczyzny repartycję sufiksów, uzależnioną od tematu bezokolicznika: tematy spółgłoskowe przyjmują sufiks - ъu, zaś samogłoskowe - sufiks - въu. Zabytki dokumentują również proste formy part. praet. act. II na $-л ъ,-л a,-л o$, wchodzące w skład perfectum, plusquamperfectum oraz trybu przypuszczającego.

W obu latopisach nom. masc. imiesłowów czasu przeszłego I charakteryzuje się repartycją końcówek uzależnioną od tematu bezokolicznika: - в (-вb) bądź zerem morfologicznym w tematach spółgłoskowych, por.: Maмau же, то видевь, и побеж 万 (50v S.), всими сими полькь вооруживься поиде на иаря Темир-Кукляя (56v S.), князь велики Евнутеи, вьскотив, убежить во гуры (88 S.), иже воротися в Бдав смерть канову (31v S.), онъ же честив и дарив его любовию, отпусти, рекьше к ним (55 S.), не достоить ти иарьствовати изгнав иаря (41 S.), приставися князь великии (...) княжив 12 лБт (40v S.), он, наредивъся в однои жонкь портьл, да за дрогою вышель (96v S.), отслуживь обедню, таки в ризах взяль одинь жребии (65 S.), Бать же послушав сов Бта Дмитрова, иде во Угрьи (32v S.), отпусти посльь рускыи и почтив их (10 S.), вчиниль есми стерега своеи головы почюв, што на мене лихо мьслить (92 S.), Володимер (...) у убоявся бЂже за море (13); а въсльишав, ижь мужики мешкають без господаря а зовутся дручане (66v K.), Олькгимонт не мало княжив $л Б т$, и умре (70 K.), повъстав иарь Батыи и пошол на Рускую землю (66v К.), и там розболевся князь в Бликыи Витовт и роспустил князеи своих (87 K.) / не поиде король немецькь Магнушь к Новгороду ратию и не дошед взя город Орехов (39 S.), иарь же Тактамышь перешед Оку взя град Серъпоховь (51 S.), и пришедь князь Михаило станеть на Рши (77v S.), и щед ратию, взя ратию Ростов и позжже (35v S.), и самь щед сед на Воложескомь иарьствии (50v S.); нЂ дошед до Вилни (87v K.), четвертыии брат его, Голшис, перешед реку Велю (72 K.), и пришед до Новагородка (70v K.). $\mathrm{W}$ Kronice supraskiej pojawiają się błędne formy masc. w znaczeniu fem.: 


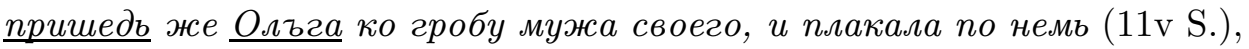
жоние дв Б ходили покладьвати княгиню в камнату, положив да вон

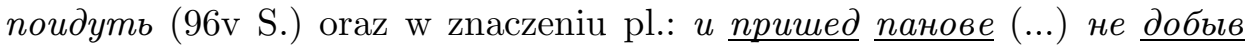
города, прочь пошли (78 S.).

Kilka przykładów zachowuje archaiczną formację typu вземь (11 S.) powstałą od dawnego bezokolicznika z samogłoską nosową, por.: вземь дань поиде домов (11 S.), и вземши с собою одного остронома (64v K.), вземши перемире (85 К.), в Бликыи Витовт Кривыи городок възем$\underline{u u}(80$ K.). Podobne formy były rozpowszechnione w zabytkach staroruskich. W procesie dalszego rozwoju języka nastąpiła unifikacja tego imiesłowu na wzór form fem. Pod koniec XV w. imiesłów вземь/вземьши całkowicie wyszedł z użycia $\mathrm{w}$ mowie żywej, zachował się jedynie $\mathrm{w}$ zabytkach piśmiennictwa, również w wariantach озем(uи) і возем(ши) [Булыка, Жураўскі, Крамко, 1979, 312]. Teksty analizowanych zabytków poświadczaja podobne przykłady dla sg. i pl.: Батыл же воземь город (32 S.), она же (..) воземьши ножь (63 S.); и возем иарство (84 K.), Витовт тогды не воземши Вилни (79v К.), н万 воземши города (89 K.).

Podobnie, jak w czasie teraźniejszym, part. praet. act. I ulegały stopniowej unifikacji do form nom. sg. fem., co w konsekwencji prowadziło do naruszenia systemu deklinacyjnego oraz wahań w rodzaju i liczbie. Formy krótkie zaczęły umacniać się w roli imiennej części orzeczenia i tym samym przekształcać w nieodmienne imiesłowy przysłówkowe. Język badanych zabytków potwierdza szereg przykładów, w których nastąpiła unifikacja form starego nom. fem. dla wszystkich rodzajów i liczb, por.: caмa (...) пришедши посла послов своих (11v S.), отпущена бысть в Киев, 므вчившися у патриярха (12 S.), великия княгини сльишавъши от людеu (96v S.), ale:

Батьии же воземь город и сльишавъши о Даниле (32 S.), князь великьии Витовть умьишливъши ему по своему хотению (67v S.), еше же и турускы иарь честь велику и многи дары и подавши (79 S.), отшедши от города Смоленского князь вликьи ${ }^{3}$ Скиригаило (100 S.);

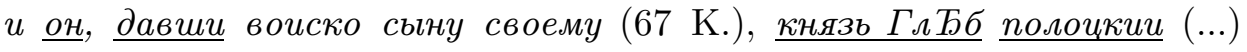
княживши немного лЋт в Полоику (68v К.), и князь великьи Скиргаило, одержавши звитежство (70 K.), и он, собравъшися з людми (66v K.), Витовт, послухавши жоны свое рады, и нарядивъшися одное жонки в плате (77v K.), князь Федор,$(.$.$) шедии з литовским воиском$ и засядеть (83 К.), пришедии князь Михаило станеть на Рии (89 К.),

3 Taki zapis pojawia się $\mathrm{w}$ latopisie. 
пришедши князь Михаило стоял под Витебском (89 K.) (w znaczeniu masc.);

болгары же видивши (5v S.), они же, сльишавши безьконечну его силу (10v S.), сльишавши др Бвляне (...) и здумавши (11 S.), татарове приехавши ко Златьль воротамь (23 S.), они (...) объехавши весь город (23v S.), татарове же искавши их (27v S.), полии Александровьи, видевъши падение шатра того (30v S.), немии пакь прускии усльишавши тая дБла (93 S.), ничего не починавши, остали (95v S.), посекши лБсь город муровали Каменець (105v S.), яхове (...) до радь не допустивши (108 S.); они (...) пошли до реки Дубисьи, где ж вшед-

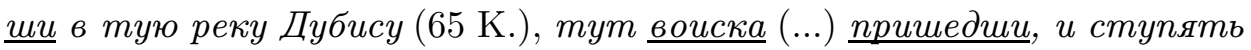
Троки (76 К.), люди полочан Б усльшавши (75v К.), и тыи княжата, розсекши лЂс (83 К.), боярЂ смоленскии, приехавши к Смоленску (90 К.), мужи полочане, ополъчившися полки своими (67v K.), пришедши панов Б стояли под Полочьком неделю (89 К.), пришедии москвичи с татарь казанскими (90v K.), москвичи, собравшися за девять днеи (90v K.) (w znaczeniu pl.).

Takie skostniałe formy nom. sg. fem. pojawiają się w zabytkach piśmiennictwa starobiałoruskiego końca XV w., jednak paralelnie jeszcze długo utrzymują się w pl. stare imiesłowy na -ше [Булыка, Жураўскі, Крамко, 1979, 311]. W pochodzącym z Kroniki supraskiej przykładzie смолвилии (88 S.) zapis $\Omega$ na miejscu sufiksalnego $в$ należy traktować jako hiperpoprawną formę powstałą pod wpływem czasowników typu бbıл, w których fonetyczna wartość $\Omega$ była równa [u] [Булыка, Жураўскі, Крамко, Свяжынскі, 1988, 258].

W starobiałoruskich zabytkach formy krótkie imiesłowów czynnych czasu przeszłego I bardzo często wchodziły w skład konstrukcji „celownika niezależnego" [Булыка, Жураўскі, Крамко, Свяжынскі, 1988, 242], co również świadczy o adwerbializacji tych części mowy, por.: бивъиися oбоимь полком (33 S.), неколи будущи тому славному господарю, бывъши ему во своемь граде (78v S.), иарю сему Давлад-Бердию немного время побьвши (81v S.), а князю Святославу, стоявши у города и бивши порокь град Имьстиславль (99v S.); много лБт княживии Скгиржгату на тых городех и умре (67v K.), мало княживши Швинторгу на Нов Бгородие (70v К.), и вмерши Роману (71v K.), и бьвии ему во своем городЂ (86 К.), тому ж Давлад-Бердею немного иарьствовавши на чарств Б (87 K.), и совокупившися им с одного (70 K.). W Kronice supraskiej paralelnie bywa stosowana forma dat. masc.: боцвию покусну в Бтру (9 S.), Борису же възвратившуся с воинь (19v S.), посхотевшю же князю Скиригаилу ехати за Днепро (103 S.), и умершу Вышеславу 
(18v S.), сему же малому Солтану щедшю на царьство (81v S.), и $\underline{\text { mо- }}$ му мимо щедию (81v S.).

Pojedyncze złożone formy imiesłowów pojawiają się jedynie w Kronice supraskiej, por.: показавшему (49v S.) (dat. masc), седЂвъшего (69v S.) (acc. masc.) oraz явлъшюся (58v S.) (acc. fem.).

Niepełny paradygmat deklinacyjny imiesłowów czasu przeszłego w pl. jest reprezentowany przez rzeczownikowe formy nom. oraz zaimkowe dat. wyekscerpowane z Kroniki supraskiej. W nom. zostały zachowane nieliczne przykłady na -ue; zdecydowana większość form pl. charakteryzuje się uogólnioną do fem. sg. końcówką - uu, por.: выехавше (22 S.), отшедше (23v S.), послушавше (32v S.), пришедше (22 S.), совещавъше (69v S.). Latopis dokumentuje również imiesłów peкьше użyty w znaczeniu sg.: онъ же честив и дарив его ююбовию, отпусти, рекьше $\kappa$ ним (55 S.).

$\mathrm{W}$ dat. konsekwentną realizację uzyskuje zaimkowa odmiana imiesłowów czynnych czasu przeszłego często wchodzących w skład konstrukcji dativus absolutus, por.: и какь нешошедшимься полькомь (94 S.), татаром же (...) разбившимь ст Бньи градныля возылолиа на валь (27 S.), симь же стареишинамь ординским сльгшавшимь (...) и придоша сами (82 S.). Inne przykłady: бивъшимь (27v S.), возбегьшимь (32 S.), изъшедиимь (27 S.), покорившимся (16v S.), попленившимь (26 S.), пришедшимь (10v S.), ступивъшимься (101 S.), усльишавшимь (29 S.), хотевъиимь (65v S.).

Udokumentowane w zabytkach formy krótkich imiesłowów czynnych czasu przeszłego II biorą udział w tworzeniu perfektu i plusquamperfektu oraz trybu warunkowego.

Najbardziej produktywnym czasem służącym wyrażeniu czynności dokonanej $\mathrm{w}$ przeszłości $\mathrm{w}$ badanych zabytkach jest perfekt, uproszczony do syntetycznej formy bez słowa posiłkowego. Wprawdzie złożona forma perfectum w 3 os. była spotykana w latopisach dość często, jednak jej użycie związane było z przywiązaniem do tradycji piśmienniczej [Дурново 2000, 304]. Stosowanie samego imiesłowu na $-л ъ,-л a,-л o \mathrm{w}$ funkcji praeteritum zaczyna wzrastać w XII-XIII w. [Stieber 1989, 232].

W analizowanych latopisach zaświadczone zostały również analityczne formy perfectum, głównie w 1 i 2 os. Por. materiał ilustracyjny:

1 os. sg.: вииниль есми (92 S.), сльишаль есми (55 S.); не вчинил есми (75 K.), почул есми (75 K.) / не азь начал (14 S.), я не вчинил (92 S.);

2 os. sg.: взал еси (45v S.), добыл еси (107 S.), еси въеднал (76v K.), добыл еси (83v K.) / тьи не в Бриль (92 S.);

3 os. masc.sg.: убил есть (13 S.), утопль есть (27 S.); сталося есть (64 K., 75 K.) / вынял (106v S.), сел (6 S.), уехаль (53 S.), хотель (73 S.); 
дал (72v K.), записался (74 K.), поразил (70v K.), поставил (85 K.), приказал (80v K.), ся урадовал (75 K.);

3 os. fem.sg.: вдов Бла (107v S.), обломилася (19v S.), собралася (97 S.); была (79v K.), ся утвердила (86 K.);

3 os. neutr.sg.: не быввло (100v S.), ся остало (77 S.), сотворилося (63 S.), шло (73 S.); доконало ся (77 K.), стало (79 K.), учинилося (74v K.), хоживало (69 K.);

2 os. pl.: есте выъхали (55 S.);

3 os. pl.: были суть (6v S.) / взяли (106 S.), зазвонили (83v S.), молвили (83v S.), целовали (83 S.); втекали (64v K.), змовили (73v K.), поимали (89 К.), хвалили (69v К.).

Wiele przykładów 3 os. masc. sg. poświadcza zmianę wygłosowego $[1]>[u$ ] $]$, która stosunkowo wcześnie nastąpiła w żywej białoruszczyźnie. W zabytkach pozostających pod silnym wpływem tradycji piśmienniczej zjawisko to nie uzyskało konsekwentnej realizacji [Булыка, Жураўскі, Крамко, Свяжынскі 1988, 198], о сzym może świadczyć również pisownia analizowanych zabytków, por. nр.: князь (...) возмужав и бысть храбрь велми (12), и тамо женивъся и крестивъся в латыньскую в Бру (52v S.), Витовът (..), колко бивъся и тружавься и не може его выстояти (59v S.), и в Смоленсте быв и зборовал (71 S.), я (...) не рушив есмо (92 S.), а как усльшшав то князь великь Витовть (93v S.); повъстав иарь Батыи и пошол на Рускую землю (66v K.), а въсльишав, ижь мужики мешкають без господаря (66v K.), Якгаило тые присяги преступив и рек так (77 K.), гостеи иестив и даровал размаитыми дары (86 K.).

We wczesnych zabytkach piśmiennictwa WKL imiesłowy rodzaju męskiego na spółgłoskę tylnojęzykową lub $c, 3$ używane były z wygłosowym - љъ. Tradycyjny sposób zapisu notują starobiałoruskie teksty jeszcze na początku XVI w., jednak od końca XV w. pojawiają się również przykłady bez wygłosowego -лъ [Булыка, Жураўскі, Крамко, Свяжынскі 1988, 195-196]. Latopis Krasińskich potwierdza wyłącznie tego typu formy: втек (70 K.), збег (66v К.), не мог (80v K.), остерег (75 K.), помог (90v K.), рек (76v K.), умер (73v K., 83 K.). W nieco starszej Kronice supraskiej przeważają tradycyjne zapisy z -лъ, por.: вьбегл (106v S.), остерегл (92 S.), посекль (69v S.), прибегьль (50 S.), рекл (91v S.) / облекься (70 S.), пас (62 S.), принесь (65 S.).

Zabytki dokumentują również dwa typy czasu zaprzeszłego - odziedziczoną z prasłowiańszczyzny konstrukcję imiesłowu na $-л ъ$ z imperfectum $\sigma_{\Delta x ъ} \mathrm{w}$ odpowiedniej formie lub tzw. „imperfektywnym aorystem” [Stieber 1989,237$]$ б $5 x ъ$ oraz nowszą, w której obok imiesłowu na -лъ poja- 
wia się perfekt od быmu. W związku z wczesnym zanikiem słowa posiłkowego w perfekcie, konstrukcja nowego plusquamperfectum uległa redukcji do dwóch wyrazów [Борковский, Кузнецов, 2007, 280]. Poświadczone w obu latopisach przykłady przyjmują wyłącznie formę 3 os. obu liczb, por.: даль быль (91 S.), взяль был (100v S.), повель был (90 S.), полюбилъся быль (90 S.), не хотела была (106 S.); полюбился был (74 K.), собралася была (77v K.), не хотел был (83 K.), хотБл был (85v K.) (masc. i fem. sg.) / записалися были (92 S.); дали были (83v K.), оставили былли (77 K.) (pl.).

W Kronice supraskiej zostały odnotowane trzy konstrukcje starszego typu plusquamperfectum z aorystem бЂ: бЂ была (13 S.) і бЂ пришел (13v S.) / бЂ дали (100v S.).

Wyekscerpowane z latopisów przykłady trybu warunkowego w sg. stanowią regularne formy $3 \mathrm{os}$. z czasownikiem posiłkowym $\sigma b l$, por.:

2 os. masc. sg.: ты бы при бхал (94v S.), штобы еси уедьналь (94v S.); тыл $б$ приехал (76v K.),

3 os. masc. sg.: бъц быль (94v S.), владел нами и судил бы (6 S.), бь даль (94v S.), понял бы (97 S., 78 K.), штобы при бхаль (94v S.), сталь бъл (97v S.), бы явил (91 S.); бы ся дивовал (64v К.), бы зжог (71 К.),

3 os. neutr. sg.: бы не было (94v S., 76v K.), бы ся достало (90v S., $74 \mathrm{~K}$.$) .$

W pl. obok tradycyjnych zapisów conditionalu z aorystyczną formą czasownika posiłkowego poświadczenie uzyskują nowe formy, por.:

1 os. pl.: штобьи въчинили быхомь (95 S.), быхомь держали (94v S.), быхомь поговорили (94 S., 76 К.); бьихмо мЂли (76v К.);

2 os. pl.: дабы есте выъхали (55v S.), держали (...) вы бы (94v S.);

3 os. pl.: бы не повоевали (24 S.), бь не приходили (80 S.); бь сожали (70v K.).

Na podstawie analizy form imiesłowowych wyekscerpowanych z Kroniki supraskiej i Latopisu Krasińskich można sformułować kilka wniosków dotyczących zmian w obrębie systemu deklinacyjnego rozpatrywanej części mowy. W obu zabytkach zaznacza się silna tendencja do zaniku imiennych form fleksyjnych badanych imiesłowów. Wyrazem tego procesu jest dominacja uogólnionej formy nom. fem. w odniesieniu do rzeczowników wszystkich rodzajów i liczb. Zjawisko to zaznacza się zwłaszcza w późniejszym Latopisie Krasińskich, por.: Ягаилу держаши стол Краковского кролевъства (79v S.); людие же видивъши вопл его (69v S.); великыи Куковочти, милуючи матку свою (69v K.), князи ордьгские, ㄷ смеючи розгн Бвати славного господаря (87 K.), прищедши москвичи с тата- 


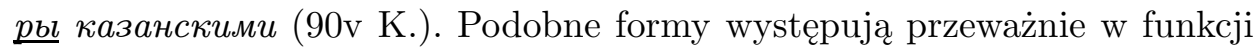
imiesłowu nieodmiennego przysłówkowego czasu teraźniejszego i przeszłego, co świadczy o ich adwerbializacji w języku starobiałoruskim badanego okresu. Zjawisko kształtowania się nowej kategorii morfologicznej w obrębie systemy partycypialnego odbyło się pod wpływem żywej wymowy i potwierdzają je teksty piśmiennictwa starobiałoruskiego z początku XVI w. [Булыка, Жураўскі, Крамко, Свяжынскі, 1988, 259]. Należy podkreślić, że w starszej Kronice supraskiej przeważają zapisy powyższych imiesłowów z sufiksem -u-, natomiast w Latopisie Krasińskich normę stanowią imiesłowy z sufiksem - ч-. O silnym związku Kroniki supraskiej z tradycją cerkiewnosłowiańską świadczą również archaiczne formy, które w żywym języku okresu powstania zabytku nie były już używane, typu: яды (14 S.), не могы (32 S.), не имь (54v S.). W Kronice supraskiej, w przeciwieństwie do drugiego z analizowanych tekstów, znalazła poświadczenie niewielka liczba form fleksyjnych odmiany złożonej imiesłowów czynnych czasu teraźniejszego i przeszłego, por.: хотящимь (27 S.), испущая (57v S.), служящего (62v S.), показавшему (49v S.), седЂвъшего (69v S.). Bogata egzemplifikację w obu zabytkach uzyskały imiesłowy czynne czasu przeszłego II wchodzące w skład perfektu, często pełniącego rolę zuniwersalizowanego praeteritum.

\section{Literatura}

Stieber Z., 1989, Zarys gramatyki porównawczej języków stowiańskich, Warszawa.

Borkovskij V.I., Kuznecov P.S., 2007, Istoričeskâ̂ grammatika russkogo âzyka, Moskva. [Борковский В.И., Кузнецов П.С., 2007, Историческая грамматика русского языка, Москва.]

Bulyka A.M., Žuraǔskì A.İ., Kramko İ.Ì., 1979, Gistaryčnaâ marfalogiâ belaruskaj movy, Mìnsk. [Булыка A.M., Жураўскі А.І., Крамко I.I., 1979, Гістарычная марфалогія беларускай мовы, Мінск.]

Bulyka A.M., Žuraǔskì A.İ., Kramko İ.Ì., Svâžynskì U.M., 1988, Mova belaruskajpis'mennasci XIV-XVIII stst, Mìnsk. [Булыка A.M., Жураўскі A.I., Крамко I.І., Свяжынскі У.М., 1988, Мова беларускай пісьменнасиі XIVXVIII cmcm, Мінск.]

Durnovo N.N., 2000, Izbrannye raboty po istoriirusskogo âzyka, Moskva. [Дурново Н.Н., 2000, Избранные работы по истории русского языка, Москва.]

Žuraǔskì A.Ì., 1961, Da pytvnnâa ab asnoǔnyh typah staražytnaj belaruskaj lìtaraturnaj movy, „Pracy İnstytuta movaznaǔstva AN BSSR”, Vyp. 8, Mìnsk, s. 106-116. [Жураўскі А.I., 1961, Да пытвнняя аб асноўньих тыпах старажытнай беларускай літаратурнай мовы, ,Працы Інстытута мовазнаўства АН БССР", Вып. 8, Мінск, с. 106-116.] 
Žuraǔskì A.İ., 1983, Mova našyh prodkaŭ, Mìnsk. [Жypay̆cki A.I., 1983, Мовa нашых продкаў, Мінск.]

Ivanov V.V., 1983, Istoričeskaâ grammatika russkogo âzyka, Moskva. [Иванов В.В., 1983, Историческая грамматика русского языка, Москва.]

Mìnnevič A.Â. (red.), 1994, Belaruskâa mova. Ėncyklapedyâ, Mìnsk [Міхневіч A.Я. (ред.), 1994, Беларуская мова. Энцыклапедыля, Мінск.]

Mikitas' V.L., 1978, Zahidnorus'ki, abo litovs'ko-rus'ki, litopisi (vitâg z pidručnika: M.S. Gricaj, V.L. Mikitas', F.Â. Šolom, Davnâ ukraïns'ka literatura, Kï̈v, s. 97-103). [Микитась В.Л., 1978, Захидноруські, або литовсько-руські, літописи (витяг з підручника: М.С. Грицай, В.Л. Микитась, Ф.Я. Шолом, Давня украӥнська література, Київ, с. 97-103).] [online] http//www. litopys.org.ua/psrl13235/lytov34htm [13.11.2007 r.]

Sobolevskij A.I., 2005, Lekcii po istorii russkogo âzyka, Moskva. [Соболевский А.И., 2005, Лекиии по истории русского языка, Москва.]

Ulaŝik N.N. (red.), 1980, Polnoe sobranie russkih letopisej, t. XXXV, Moskva, s. 36-67 i s. 128-144. [Улащик Н.Н. (red.), 1980, Полное собрание русских летописей, t. XXXV, Москва, s. 36-67 і s. 128-144.]

Čemerickij, V.A., 1981, Rabota avtora pervogo belorussko-litovskogo svoda nad russkimi istočnikami, [w:] B.A. Rybakov (red.), Letopisi i hroniki 1980. V.N. Tatiŝev i izučenie russkogo letopisaniâ,, Moskva., s. 182-190. [Чемерицкий, В.А., 1981, Работа автора первого белорусско-литовского свода над русскими источниками, [w:] Б.А. Рыбаков (red.), Летописи и хроники 1980. В.Н. Татищев и изучение русского летописания, Москва, s. $182-190$.

\section{CONVERSIONS WITHIN THE SYSTEM OF ACTIVE PARTICIPLES IN THE OLD BELARUSIAN LANGUAGE \\ BASED ON SELECTED BELARUSIAN-LITHUANIAN CHRONICLES}

ABSTRACT

Key words: chronicle writing of the Grand Duchy of Lithuania, the Old Belarusian Language, morphology, active participles

This article focuses on 16th-century written monuments of the Grand Duchy of Lithuania, representing the first and second Belarusian-Lithuanian redactions. Their common part - the Chronicle of Grand Dukes of Lithuania - was created in the Grand Duchy of Lithuania. The article analyses the changes occurring in the system of Old Belarusian active participles and compares them with all-Ruthenian state. The analysis has shown that in the participle system, on the one hand, some forms, such as inflectional forms of complex declension of active participles, tended to decline. On the other hand, a new morphological category was emerging, namely, undeclinable adverbial present and past participle. 